TITLE:

\title{
Variations in turbulent energy dissipation and water column stratification at the entrance of a tidally energetic strait
}

\section{AUTHOR(S):}

Kobayashi, Shiho; Hashimoto, Eisuke; Nagao, Masayuki; Takasugi, Yoshio

\section{CITATION:}

Kobayashi, Shiho ... [et al]. Variations in turbulent energy dissipation and water column stratification at the entrance of a tidally energetic strait. Journal of Oceanography 2009, 65(5): 657-664

\section{ISSUE DATE:}

2009-10

URL:

http://hdl.handle.net/2433/89643

\section{RIGHT:}

c 2009 Springer Science+Business Media B.V.; この論文は出版社版であ りません。引用の際には出版社版をご確認ご利用ください。; This is not the published version. Please cite only the published version. 
1 Title

2 Variations in turbulent energy dissipation and water column stratification at the

3 entrance of a tidally energetic strait

4

5 Authors

6 Shiho Kobayashi ${ }^{*}$, E isuke Hashimoto², Masayuki Nagao³, Yoshio Takasugi2

7

8 *corresponding author

9 e-mail address: shihok@kais.kyoto-u.ac.jp

10 tel: $+81-75-753-6216$

11

121 Graduate School of Agriculture, Kyoto University, Kitashirakawaoi wake, Sakyo,

13 Kyoto, 606-8502, J apan

2 National Institute of Advanced Industrial Science and Technology (AIST

16 Chugoku), 2-2-2, Hiro, Kure, Hiroshima, 737-0197,J apan

17

3 National Institute of Advanced Industrial Science and Technology (AIST

19 Tsukuba), 1-1-1, Tsukuba-Higashi, I baragi, 305-8567,J apan

Abstract

We observed tidal currents, turbulent energy dissipation and water column stratification at the entrance of a narrow strait (Neko Seto) in the Seto Inland Sea, Japan, using a free-falling turbulence micro-structure profiler (TurboMap) and Acoustic Doppler Current Profiler (ADCP). The variation in turbulent energy dissipation at the entrance of the strait was not at quarter-diurnal frequency but at semi-diurnal frequency; turbulent energy dissipation was enhanced during the ebb tide, although it was moderate during the flood tide. This result is consistent with the results of Takasugi (1993), which showed the asymmetry of tidal energy loss during a semi-diurnal tidal cycle using control volume analysis. It is suggested that 
31 significant turbulent energy dissipation is generated in the strait, which influences

32 the properties of water outside the strait when tidal currents flow out from the 33 strait.

34

35

48 日本語要旨

49 自由落下式乱流微細構造プロファイラ (TurboMap) 及び 超音波ドップラー流速計

50 (ADCP)を用いて瀬戶内海の海峡部 (猫瀬戶) 入口において潮流, 乱流エネルギー逸散 51 率及び物理構造の観測を行なった . 猫瀬戶入口における乱流エネルギー逸散率は $\mathrm{M}_{4}$ 周

\section{Running Title}

turbulent energy dissipation at the entrance of a tidally energetic strait

\section{Keywords}

tidal currents; turbulent energy dissipation; tidal variation; tidally energetic strait;

Seto Inland Sea

和文タイトル

潮流の強い海峡部開口部付近における乱流エネルギー逸散および水柱構造の変動

日本語著者名

小林志保・橋本英資・長尾正之・高杉由夫
53 が, 上げ潮流の増大は比較的穏やかであった .この結果は, コントロールボリューム法 54 を用いて潮汐エネルギーの損失が上げ潮流時と下げ潮流時とで異なることを示した高 杉 (1993) の結果と一致している.下げ潮流時には海峡内において大きな乱流エネルギ 一逸散が生じ，さらに海峡外の水の性質に大きな影響を及ぼすことが示唆された .

\section{Introduction}

The Seto Inland Sea is a semi-enclosed coastal sea connected to the Pacific Ocean 
60 through two openings separated by an along-channel distance of $\sim 550 \mathrm{~km}$. It

61 resembles an archipelago due to the presences of hundreds of islands and a number

62 of narrow straits where strong tidal currents generate vigorous stirring. The spatial pattern of varying stratification is reflected to a considerable degree in the distributions of biochemical properties in the Seto Inland Sea; in most straits, vertical differences in nutrients and chlorophyll are small or negligible, while, in the stagnant basins, there are pronounced vertical differences associated with density stratification (Kobayashi et al., 2006). Turbulent mixing may play an important role in controlling the water column stratification.

The tidal cycle of turbulent energy dissipation has been studied previously in coastal and shelf seas (e.g., Simpson et al., 2002; Inall et al., 2004; Souza et al., 2008). Rippeth et al. (2003) illustrated the tidal cycle of turbulent energy dissipation in an energetic tidal flow, while Matsuno and Nakata (2004) showed this in Ariake Bay, Japan. Although the interaction between tidal currents and turbulent energy dissipation in these shelf seas or bays has been demonstrated, few studies have been conducted on turbulence measurements in the straits in archipelagos.

77 Yamazaki et al. (2006) first provided microstructural data in a tidally energetic strait in the Seto Inland Sea (Neko Seto, 340' $10^{\prime} \mathrm{N}, 132^{\circ} 30^{\prime} \mathrm{E}$ ) obtained from a turbulent micro-structure profiler (TurboMAP, Wolk et al., 2002). Mitchell et al. (2008) also published the results of observations in the Neko Seto, with microscale profiles with considerable structure, particularly shear. The tidal cycle in turbulent microstructures in such straits has not been fully elucidated.

This study presents a tidal cycle of turbulent microstructure obtained from TurboMAP at the entrance of Neko Seto, a tidally energetic strait in the Seto Inland Sea. We first demonstrate the temporal variations in turbulent energy dissipation, temperature and conductivity measured using TurboMAP. The temporal variation in tidal energy dissipation is interpreted on the basis of flow fields measured using an Acoustic Doppler Current Profiler (ADCP). 


\section{Study Area}

91 The study area is located at the entrance of the narrow strait Neko Seto in the Seto

92 Inland Sea (Fig. 1b). The width of the narrowest part of the strait is about $1.5 \mathrm{~km}$, with the width increasing exponentially at the strait's entrance. The topography of the study area is complicated, with depth varying from 10 to $110 \mathrm{~m}$ (Fig. 1c). Takasugi (1993) described the distribution of the amplitude of the $\mathrm{M}_{2}$ tidal current in Neko Seto obtained from long-term mooring of a current meter. The amplitude at the narrowest part exceeds $1.5 \mathrm{~m} \mathrm{~s}^{-1}$, while far from the narrowest part it is around $0.1 \mathrm{~m} \mathrm{~s}^{-1}$. As with all straits in the Seto I nland Sea, the narrowest part in Neko Seto, where the amplitude of the tidal current is largest, is the deepest. This is attributed to the intensified tidal currents eroding the seabed (Takeoka, 2002).

Maximum ebb and flood currents in this region appear around 2 hours before low and high water, respectively (Takasugi, 1987). When tidal currents pass through the strait, tidal jets accompanied by significant horizontal shear are formed at the entrance. Takasugi et al. (1989) described the sheared flow according to ADCP measurement, finding significant tidal energy loss within the sheared flow. Tidal vortexes are also formed in this region, similar to those at the entrances of Akashi and Naruto Straits (Takasugi, 1987). The topography and tidal currents in the study area are thus extremely complicated.

Takasugi (1993) revealed the tidal energy balance in the study area, based on the results of the current measurements at the stations indicated by circles in Fig. 1c $(\mathrm{C} 1 \sim \mathrm{C} 6)$ and sea level measurements at four points around the strait (details of the analysis are shown in the Appendix). Fig. 2 shows the temporal variations in each term, estimated using control volume analysis. He found that the energy loss, $E_{f}$,

114 reaches $2.5 \times 10^{4} \mathrm{~W} \mathrm{~m}^{-1}\left(\sim 0.5 \mathrm{~W} \mathrm{~m}^{-3}\right.$ when divided by the sectional area) during maximum ebb. He also found that the magnitude of $E_{f}$ changes according to the

116 current direction; it became larger in westward (ebb tide) than that in eastward 117 flow (flood tide). 


\section{Methods}

\section{3-1. Observation Program and Meteorological Condition}

Observations were made on 6 J uly, 2005, from 07:30 to 20:30 h, J ST, covering a complete $\mathrm{M}_{2}$ tidal cycle. It was cloudy and the weather was calm on the observation date. Daily mean wind speed obtained by the J apan Meteorological Agency at a weather station in Kure (the location of Kure is shown in Fig. 1b) was $1.5 \mathrm{~m} \mathrm{~s}^{-1}$ and hourly changes in wind speed were insignificant.

The locations of the stations are shown in Fig. 3. The ship ran between stations 1

127 to 4 during the observation period, stopping at each station for 5 minutes to measure currents and turbulent microstructures according to the methods described below. A total of 14 measurements were taken at each station during the observation period.

131

\section{3-2. Flow Fields and Velocity Shear}

Bottom-track velocities were obtained for a period of 5 minutes at 2-second intervals at each station using a ship-mounted Acoustic Doppler Current Profiler (ADCP) (R. D. Instruments) operating at $600 \mathrm{kHz}$ through four beam transducers directed 20 degrees from the vertical. The first ADCP measurement bin was set immediately below the blanking interval (3.1 $\mathrm{m}$ depth), and subsequent bins sampled down to the bottom at $2 \mathrm{~m}$ intervals in bottom track mode. Velocities could not be obtained at the bottom and in the surface $10 \%$ of the water depth. Data at station 4 at 15:50 h were obtained only in the upper $30 \mathrm{~m}$, for reasons unknown.

The data obtained from ADCP were corrected using pitch and roll data provided by a tiltmeter. Velocity data in which Percent Good value of beam velocity was less than $80 \%$ were removed. The remaining data were averaged to obtain the profile at each station for each cycle.

145 The squared velocity shear $\left(\mathrm{S}^{2}\right)$ was then calculated at $2 \mathrm{~m}$ intervals using the following equation: 
$148 \quad S^{2}=\left(\frac{\partial u}{\partial z}\right)^{2}+\left(\frac{\partial v}{\partial z}\right)^{2}$

where $\mathrm{z}$ is the vertical coordinate and $\mathrm{u}$ and $\mathrm{v}$ are the eastward and northward components of velocity, respectively. These values were interpolated into $1 \mathrm{~m}$

152 interval data.

153

\section{3-3. Turbulent Microstructure}

The vertical profiles of turbulent microstructure were measured using a Turbulent Ocean Microstructure Acquisition Profiler (TurboMAP) (Wolk et al., 2002). The instrument used was a free-falling profiler that carries microstructure sensors, Conductivity-Temperature-Depth (CTD) sensors, and internally mounted accelerometers. The buoyancy of the instrument was adjusted to provide a free-fall sinking velocity of $0.7 \mathrm{~m} \mathrm{~s}^{-1}$, and the signals were sampled at $512 \mathrm{~Hz}$. Data were used from the depth range in which the time-rate-change of the sinking velocities was less than $0.035 \mathrm{~m} \mathrm{~s}^{-1}$ (the mechanical error of sinking velocity; $\sim 5 \%$; Oakey and Elliott, 1970). To avoid data contamination due to initial perturbation of the instrument, data in the surface layer $(\sim 4 \mathrm{~m})$ were removed.

We dropped the TurboMAP after waves and visible bubbles generated by the screw of the ship had dissipated and pulled it up after the instrument reached the bottom. Shear data in the bottom $30 \mathrm{~cm}$ could not be obtained because of the shear probe protector. Data below $90 \mathrm{~m}$ at station 4 were not obtained when the tidal current was strongest (at $14: 10 \mathrm{~h}$ and $14: 50 \mathrm{~h}, \mathrm{~J}$ ST), because significant upward velocities prevented the instrument from sinking.

171 Shear data were processed using the software tmTools, which uses a variable

172 integration method to avoid mechanical vibrations and electronic noise. To compute 173 the turbulent kinetic energy dissipation rate $(\epsilon)$, power spectra were obtained from

174 the observed shear data by F ourier transform every 512 points (overlap 256 points).

175 The spectra were corrected by the method of Oakey (1982). The spectra were then 
176 integrated over an appropriate wave number band. The range of integration was

177 determined on the basis of fitting the Universal Spectrum (Nasmyth, 1970) to the 178 observed spectrum.

179

180

\section{Results}

181

Fig. 4 shows the temporal variations in tidal height on 6 J uly 2005 (from 08:00 to 20:00 h, J ST) predicted using tidal constituents $\left(M_{2}, S_{2}, K_{1}, O_{1}\right)$ provided by the Maritime Safety Agency, J apan. The first high water was identified at 09:00 h; ebb tide started thereafter. Low water was found at 15:00 h; the flood tide then started and the subsequent high water appeared around 21:30 h.

A semi-diurnal variation in water column stratification was observed in the study area; axial sections of water temperature, salinity and density in the upper layer ( 0 $\sim 40 \mathrm{~m}$ ) around 09:00 $\mathrm{h}$ (high water), 13:00 h (ebb tide), 15:00 h (low water) and 18:00 h (flood tide) are shown in Fig. 5. A source of low-salinity, warm water existed around the station farthest from the strait (Sta. 1). At high water (Fig. 5 a $\sim$ c), the low-salinity, warm water spread over the layer above $10 \mathrm{~m}$, reaching the station closest to the strait (Sta. 4). Both temperature and salinity in the layer below $10 \mathrm{~m}$ were almost uniform throughout the study area. Density was also almost uniform in the layer below $10 \mathrm{~m}$, with only one isopycnal tilted upward toward the strait.

During ebb tide (Fig. $5 \mathrm{~d} \sim \mathrm{f}$ ), the low-salinity, warm water was pushed back toward Sta. 1. The thermocline, halocline and pycnocline in the surface layer were unstrained, and part of surface warm water was mixed with water in the lower layer at Sta. 4. A high-salinity water mass (32.8 psu) was found around the bottom of Stas. 2 and 3. Density was still almost uniform in the layer below $5 \mathrm{~m}$, with only one isopycnal tilted downward toward the strait. At low water (Fig. $5 \mathrm{~g} \sim \mathrm{i}$ ), the low-salinity, warm water was found only at Sta. 1, and the thermocline, halocline and pycnocline were intensified and moved up to the near-surface. A high-salinity water mass (32.8 psu) left the strait and was found on the bottom of Sta. 1. During flood tide (Fig. $5 \mathrm{j} \sim \mathrm{I}$ ), the low-salinity, warm water began to spread toward the 
205

206

207

208

209

210

211

212

213

214

215

216

217

218

219

220

221

222

223

224

225

226

227

228

229

230

231

232

233

strait.

Fig. 6 shows semi-diurnal variations in the eastward and northward components of velocity $\left(\mathrm{m} \mathrm{s}^{-1}\right)$ measured using ADCP. The data show that the tidal currents in this region generally flow to the northeast during the flood and to the southwest during the ebb tide. At the stations far from the strait (Stas. 1 and 2), the direction of the currents changed from the northeast to the southwest at high water, and from the southwest to the northeast at low water. At the stations near the strait (Stas. 3 and 4), the currents show considerable irregularity during ebb tide; they were directed to the northeast at high water but turned to the southwest thereafter, then returned to the northeast. Vertical shear of velocities was also significant at low water at Sta. 4. The results indicate that complicated current structures are induced at the entrance of the strait when tidal currents flow out from the narrowest part. At the station farthest from the strait and shallowest (Sta. 1), velocities decreased toward the bottom. At the other stations, in contrast, velocities did not always decrease toward the bottom and sometimes velocities in the lower layer were higher than those in the upper layer.

In order to compare the magnitude of tidal currents between ebb and flood tides at the bottom of each station, temporal variations in velocities $\left(\mathrm{m} \mathrm{s}^{-1}\right)$ in the surface and bottom layers are shown in Fig. 7. Bottom velocities are higher during the flood than the ebb tide at all of the stations. Surface velocities are higher during the flood than the ebb tide at Stas. $1 \sim 2$, while they are larger during the ebb than the flood tide at Stas. $3 \sim 4$. The maximum ebb tides are found about 2 hours before low tide, while the maximum flood tides are found about 3 hours before high tide.

Fig. 8 shows semi-diurnal variations in the squared velocity shear $\left(\mathrm{s}^{-2}\right)$ calculated using the results from ADCP observation, and turbulent energy dissipation $\left(\log _{10} \epsilon\right.$ $\mathrm{W} \mathrm{m}^{-3}$ ) measured using TurboMAP. At all stations, velocity shear near bottom was slightly higher during the flood tide than the ebb. There was a correlation between the variations in turbulent energy dissipation near the bottom and those in velocity shear, in that turbulent energy dissipation increased with velocity shear. At the 
234

235

236

237

238

239

240

241

242

243

244

245

246

247

248

249

250

251

252

253

254

255

256

257

258

259

260

261

262

shallowest station (Sta. 1), velocity shear and turbulent energy dissipation were generally greater than the values at the other stations, reaching near to the surface during flood tide.

At Stas. $2 \sim 4$, significant turbulent energy dissipation was found not only near the bottom but also in the middle layer around low water. At Stas. $2 \sim 3$, significant velocity shear was found only near bottom, so the energy dissipation found in the middle layer at these stations correlated poorly with velocity shear. At Sta. 4, significant velocity shear and turbulent energy dissipation were observed in the middle layer around low water. The peak dissipation rate at Stas. $2 \sim 3$ and Sta. 4 reached $\sim 3 \times 10^{-3} \mathrm{~W} \mathrm{~m}^{-3}$ and $10^{-1} \mathrm{~W} \mathrm{~m}^{-3}$, respectively.

Vertical profiles of the eastward component of velocity measured using ADCP (m $\left.\mathrm{s}^{-1}\right)$, and shear $\left(\mathrm{s}^{-1}\right)$ and salinity (psu) measured using TurboMAP are shown in order to examine the variation in turbulent energy dissipation at Sta. 4 (Fig. 9). Note that shear shown in Fig. 9 is obtained from the microstructure profiler, which is different from the vertical shear shown in Fig. 8. At high water the shear signal showed variations with peak value of $0.02 \mathrm{~s}^{-1}$, corresponding to a turbulent energy dissipation rate of $10^{-4} \mathrm{~W} \mathrm{~m}^{-3}$. During the ebb the shear increased, reaching $0.2 \mathrm{~s}^{-1}$, while the corresponding turbulent dissipation rate was $\sim 10^{-1} \mathrm{~W} \mathrm{~m}^{-3}$.

At high water, salinity profiles showed a vertical difference of 0.2 between the surface and the bottom, and only one halocline was identified around $60 \mathrm{~m}$. During the ebb the salinity profile showed a fine structure with many overturns. At the same time, the vertical salinity difference between the surface and the bottom began to decline. At low water salinity above $80 \mathrm{~m}$ was homogeneous, while high-salinity water was found in the layer below $80 \mathrm{~m}$. The profile after low water was completely linear, and vertically averaged salinity was lower than at high water.

\section{Discussion}

During the observation period wind speed was around $1.5 \mathrm{~m} \mathrm{~s}^{-1}$ and hourly 
263 changes in wind speed were insignificant. The profiles and distribution of water density indicated that the influence of wind stirring was confined within the layer above $\sim 2 \mathrm{~m}$. There was no evidence of the influence of wind stirring on relatively uniform dissipation through the water column $(\sim 110 \mathrm{~m})$ observed in this study. The variation in turbulent energy dissipation described in the following is in the absence of wind stirring.

Several studies (e.g. Simpson et al., 1996) showed a predominantly quarter-diurnal variation in turbulent energy dissipation which was strongest near the bed, suggesting significant turbulence originating from the bottom boundary layer twice per semi-diurnal cycle. The variations in turbulent energy dissipation observed in this study, by contrast, were not at quarter-diurnal but at semi-diurnal frequency; turbulent energy dissipation was enhanced during the ebb tide, although it was moderate during the flood.

The asymmetry of turbulent energy dissipation during the ebb and flood tide has been shown by Souza et al. (2008) in the presence of a significant horizontal density gradient. They suggested that Straining Induced Periodic Stratification (SIPS; Simpson et al, 1990) would induce a quarter-diurnal variation in turbulent energy dissipation; turbulence is suppressed by the periodic stratification, while it is enhanced by the reverse differential advection of the stratified water. In our results, by contrast, major asymmetry in turbulent energy dissipation was found in the middle and bottom layers, although density gradients were only formed in the surface layer. The semi-diurnal variation in turbulent energy dissipation might be induced by the other processes.

The higher turbulent energy dissipation near the bottom at all stations during the flood tide is consistent with the greater tidal currents in the bottom layer (Fig. 7). It is suggested that the variations in turbulent energy dissipation near the bottom are strongly influenced by variations in the magnitude of tidal currents in the bottom layer. The tendency for the turbulent energy dissipation in the middle layers of Stas. $3 \sim 4$ to be higher during the ebb than during the flood tide is also 
292

293

294

295

296

297

298

299

300

301

302

303

304

305

306

307

308

309

310

311

312

313

314

315

316

317

318

319

320

partly consistent with greater tidal currents and the associated vertical shear of velocities (Fig. 7, Fig. 8).

The maximum turbulent energy dissipation observed throughout the water column at Stas. $2 \sim 4$ around low water, after velocities have decreased, however, can not be explained only in terms of the variation in the magnitude of the tidal currents. There is no evidence of an influence of turbulence originating from the bottom boundary layer on the observed, relatively uniform dissipation throughout the water column at these stations. Similar structures have been shown in the shear profiles observed in the studies of Yamazaki et al. (2006) and Mitchell et al. (2008) in Neko Seto.

Tidal currents in the study region flow out from the narrowest part during the ebb and flow in during the flood tide. Significant turbulent energy dissipation was observed at the station nearest the strait (Sta. 4) when tidal currents flow out from the narrowest part (Fig. 8). The velocity shear calculated using ADCP results was significant at low tide. Enhanced turbulent energy dissipation throughout the water column was also observed at Stas. 2 and 3 around low tide, although the velocity shear calculated using results from ADCP was insignificant at Stas. 2 and 3 at that time. Time lags in the maximum dissipation in the middle layer were found between these stations (Stas. 2, 3 and 4). The time lags and the imbalance of the production and dissipation of turbulent kinetic energy implies that turbulent water generated in the strait may be transported and influence the properties of water at these stations located outside the strait when tidal currents flow out from the narrowest part.

Takasugi (1993) showed the temporal variation of tidal energy loss in the strait using control volume analysis (Fig. 2; details of the analysis are shown in the Appendix). Irregularity of tidal currents is generally clearer when they flow out from the narrowest part than when they flow in (Takasugi, 1987). It has been suggested that the variation of the irregularity of tidal currents may possibly have caused the asymmetry of the energy loss in the strait. The present study has 
321

established the asymmetry of turbulent energy dissipation in the middle layer of the stations outside the strait. The asymmetry of turbulent energy dissipation outside the strait is largely controlled by the direction of tidal currents and consequently varies at semi-diurnal frequency.

The vertical profiles of temperature and salinity at the station nearest to the strait (Sta. 4) showed the process by which turbulent mixing produces an irreversible conversion of water. Although the vertical differences were identified at high water, the profiles showed step-like structures during the ebb tide, with numerous thermal and saline inversions appearing thereafter. In the middle of the ebb tide the shear was most significant and the turbulent energy dissipation rate exceeded $\sim 10^{-2} \mathrm{~W} \mathrm{~m}^{-3}$. The vertical differences diminished completely after this strong turbulent mixing was observed. Turbulent mixing thus plays an important role in forming a completely mixed water column around the strait.

\section{Conclusion}

This study has found a semi-diurnal variation in turbulent energy dissipation using a microstructure profiler at the entrance of a tidally energetic strait in the Seto Inland Sea. The results show evidence of significant energy dissipation throughout the water column at the entrance of the strait. They also demonstrate the asymmetry of turbulent energy dissipation in a semi-diurnal tidal cycle, which has been shown by control volume analysis (Takasugi, 1993).

\section{Acknowledgements}

Tidal constituents in the study area were provided by the Maritime Safety Agency. The observations were financially supported by the National Institute of Advanced Industrial Science and Technology (AIST Chugoku) and by the Nippon Foundation. The authors wish to express their sincerest appreciation for this support.

\section{References}


350 Inall, M., F. Cottier, C. Griffiths and T. Rippeth (2004): Sill dynamics and energy

351 transformation in a jet fjord. Ocean Dynamics, 54, 307-314.

352

353 Kobayashi, S., J. H. Simpson, T. Fujiwara and K.J . Horsburgh (2006): Tidal stirring 354 and its impact on water column stability and property distributions in a 355 semi-encl osed shelf sea (Seto Inland Sea, J apan). Cont. Shelf Res., 26, 1295-1306.

356

357 Matsuno, K. and H. Nakata (2004): Physical Processes in the Current Fields of 358 Ariake Bay. Bulletin on Coastal Oceanography, 42, 11-17.

359

360

Mitchell, J . G., H. Yamazaki, L. Seuront, F. Wolk, and H. Li (2008): Phytoplankton

361

patch patterns: Seascape anatomy in a turbulent ocean. J. Marine Systems, 69,

362

247-253.

363

364 Nasmyth, P. W. (1970): Ocean turbulence. Ph. D. Thesis, Univ. Of British Columbia, 365

Vancouver, Canada, 69 pp.

366

367

Oakey, N. S. and J. A. Elliott (1980): The Variability of temperature gradient microstructure observed in the Denmark Strait. J. Geophys. Res.-Oceans, 85, 1933-1944.

370

371 Oakey, N. S. (1982): Determination of the rate of dissipation of turbulent energy

372 from simultaneous temperature and vel ocity shear mi crostructure measurements. J .

373 Phys. Oceanogr.,12, 256-271.

374

375 Peters, H. (1999): Spatial and temporal variability of turbulent mixing in an estuary.

376 J. Marine Research, 57, 805-845.

377

378 Simpson, J. H., J . Brown, J . Matthews and G. Allen (1990): Tidal Straining, density 
379 currents, and stirring in the control of estuarine stratification. Estuaries, 13, $380 \quad 125-132$.

381

382 Simpson, J. H., H. Burchard, N. R. Fisher and T. P. Rippeth (2002): The 383 semi-diurnal cycle of dissipation in a ROFI: model-measurement comparisons. Cont. 384 Shelf Res., 22, 1615-1628.

385

386

Simpson, J . H., W. R. Crawford, T. P. Rippeth, A. R. Campbell and J . V. S. Cheok

387 (1996): The Vertical Structure of Turbulent Dissipation in Shelf Seas. J ournal of Physical Oceanography, 26, 1579-1590.

389

390

Souza, A. J ., N. R. Fisher, J . H. Simpson and M. J . Howarth (2008): Effects of tidal 391 straining on the semidiurnal cycle of dissipation in the Rhine region of freshwater influence: Comparison of model and measurements. J . Geophys. Res.-Oceans, 113, C01011.

394

395

Takasugi, Y. (1993): Fine structures of the tidal current in and around the straits and their functions in sediment transport. Reports of Chugoku National Industrial Research Institute, 11, 127 pp.

398

399

Takasugi, Y. (1987): Characteristics of velocity distributions in a strait: current

400 measurements by Doppler Current Profiler. La mer, 25,167-174.

401

402 Takasugi, Y. (1989): Formation of sand banks due to tidal vortices around strait. J .

403 Oceanography, 50, 81-98.

404

405 Takeoka, H. (2002): Progress in Seto Inland Sea Research. J. Oceanography, 58, 406 93-108.

407 
408 Wolk, L. and R. G., A. Lueck (2002): New Free-Fall Profiler for Measuring 409 Biophysical Microstructure. J. Atmospheric and Oceanic Technology, 19, 780-793.

410

411 Yamazaki, H., J. G. Mitchell, L. Seuront, F. Wolk and H. Li (2006): Phytoplankton

412 microstructure in fully developed oceanic turbulence. Geophysical Res. Lett.,33, 413 L01603.

414

415

$416 \quad$ Figure Captions

417 Fig. 1.

418 (a) Location of the Seto Inland Sea. (b) Location of Neko Seto, one of the straits in 419 the Seto Inland Sea. The study area covers the entrance of Neko Seto. Circle 420 indicates the position where harmonic constants were obtained by the Maritime 421 Safety Agency. (c) Bathymetry of the Neko Seto. Cntours indicate water depth in 422 meters (contour interval $=10 \mathrm{~m}$ ). Stations indicated by circles $(\mathrm{C} 1 \sim \mathrm{C} 6)$ and dotted 423 lines marked 'A' and 'B' were used in Takasugi (1993).

424

425 Fig. 2.

426 Temporal variations in terms of equation of tidal energy balance applied to the 427 study area (after Takasugi, 1993). $E_{t}, E_{k}, E_{p}$, and $E_{f}$ indicate time rate of change of 428 kinetic energy, divergence of kinetic energy flux, divergence of potential energy flux, 429 and energy loss, respectively. $E_{w}$ and $W_{w}$ indicate the direction of tidal flows, 430 eastward and westward, respectively.

431

432 Fig. 3.

433 Map of the study area. Black circles indicate observation points (stations $1 \sim 4$ ). 434 Numbers in parentheses denote water depths at these points. Arrows show the 435 directions of flood and ebb tide in the study area. 
437 Fig. 4.

438 Temporal variations of tidal height $(\mathrm{m})$ at the point located at the western end of the

439 study area (see Fig. $1 b)$ on 6 J uly 2005 , predicted using tidal constituents $\left(M_{2}, S_{2}, K_{1}\right.$,

$440 \mathrm{O}_{1}$ ) provided by the Maritime Safety Agency, J apan.

441

442 Fig. 5.

443 Distributions of (a) temperature ( $\operatorname{deg} C)$, (b) salinity (psu) and (c) sigma-t in the 444 upper layer $(0 \sim 40 \mathrm{~m})$ in the axial sections observed at 09:45 $\mathrm{h}$ (high water) $(\mathrm{a} \sim \mathrm{c})$, 445 13:00 h (ebb tide) $(\mathrm{d} \sim \mathrm{f}), 15: 20 \mathrm{~h}$ (low water) $(\mathrm{g} \sim \mathrm{i}$ ) and 18:30 h (flood tide) $(\mathrm{j} \sim \mathrm{l}$ ) on 6 446 J uly 2005; all times in J ST. Contour intervals are 0.1. Ticks above each figure 447 indicate observation points. Station locations are shown in Fig. 3.

449 Fig. 6.

450 (a, c, e, g) Temporal variations in eastward components of velocities ( $\mathrm{m} \mathrm{s}^{-1}$ ) 451 measured using ADCP on $6 \mathrm{~J}$ uly 2005 at stations $1 \sim 4$. Positive and negative values 452 are eastward and westward, respectively. (b, d, f, h) Temporal variations in 453 northward components of velocities $\left(\mathrm{m} \mathrm{s}^{-1}\right)$. Positive and negative values are 454 northward and southward, respectively. Velocity data taken at $2 \mathrm{~m}$ intervals are 455 vertically interpolated to make a $1 \mathrm{~m}$ interval dataset. Color bars are shown on the 456 right side of the panels. Contour intervals are $0.05\left(\mathrm{~m} \mathrm{~s}^{-1}\right)$. Broken lines in each 457 figure indicate water depths at the stations. Ticks above each figure indicate the 458 time of measurement. Data between measurements are obtained by linear 459 interpolation.

460

461 Fig.7.

462 Temporal variation in velocities $\left(\mathrm{m} \mathrm{s}^{-1}\right)$ measured using ADCP on $6 \mathrm{~J}$ uly 2005 at (a) 463 Sta.1, (b) Sta.2, (c) Sta.3 and (d) Sta.4. Thin lines with open squares and thick lines 464 with closed squares show the velocities in the surface and bottom layers, 465 respectively. Surface layers are set to $5 \mathrm{~m}$ at all stations, while the bottom layers are 
set to $11 \mathrm{~m}, 25 \mathrm{~m}, 51 \mathrm{~m}$ and $103 \mathrm{~m}$ at Sta. 1, 2, 3 and 4, respectively.

467

468 Fig. 8.

469 (a, c, e, g) Temporal variation in squared velocity shear $\left(\mathrm{s}^{-2}\right)$ calculated using the

470 results from ADCP shown in Fig. 6. Color bar is shown on the upper right side of the

471 panels. Contour intervals are $0.002\left(\mathrm{~s}^{-2}\right) .(\mathrm{b}, \mathrm{d}, \mathrm{f}, \mathrm{h})$ Temporal variation in turbulent

472 energy dissipation $\left(\log _{10} \in \mathrm{W} \mathrm{m}^{-3}\right)$ measured using TurboMAP on $6 \mathrm{~J}$ uly 2005 at

473 stations $1 \sim 4$. Color bar is shown on the lower right side of the panels. Contour

474 intervals are 0.5. Broken lines in each figure indicate water depths at the stations.

475 Ticks above each figure indicate the time of measurement.

476

477 Fig. 9.

478 Vertical profiles of the eastward component of velocity measured using ADCP ( $\left.\mathrm{m} \mathrm{s}^{-1}\right)$,

479 and shear $\left(\mathrm{s}^{-1}\right)$ and salinity (psu) measured using TurboMAP at station 4 at (a) 10:10

480 h (high water), (b) 13:20 h (ebb tide), (c) 15:45 h (low water), and (d) 16:30 h (flood

481 tide) on 6 J uly 2005.

482

483 Appendix

484 Analysis of tidal energy balance in Neko Seto (Takasugi, 1993)

485 Tidal energy balance in the study area was investigated by Takasugi (1993), on 486 the basis of the results of the continuous observations conducted in 1988. In the 487 observations, pressure sensors were set up at four points around the strait to 488 measure hourly sea level. Two ships mounted ADCP ran for 25 hours from $14-15$ 489 September 1988 to measure the current velocities al ong the two sections label ed ' $A$ ' 490 and 'B' in Fig. 1C.

491 Based on these data, tidal energy balance between sections $A$ and $B$ was 492 estimated. Assuming the currents in the strait can be treated as one-dimensional 493 flow, the balance of energy is represented as: 
$495 \frac{\partial}{\partial t}\left[\int_{S} \frac{1}{2} \rho u^{2} d S\right]+\frac{\partial}{\partial x}\left[\int_{S} \frac{1}{2} \rho u^{3} d S\right]+\rho g Q \frac{\partial h}{\partial x}=-E_{f} \quad$,

496 where $\rho$ is the density, $g$ is the gravitational acceleration, $h$ is the water depth, $t$ is

497 time, $x$ is the distance along the strait, $u$ is the velocity orthogonal to the sections

498 and $S\left(=5 \times 10^{4} \mathrm{~m}^{2}\right)$ is the average area of the sections. $Q$ is the volume flux

499 through the section, which is represented as $Q=\overline{U S}$, where $\bar{U}=\int_{S} u d S / S$ is the

500 sectional averaged velocities. The first term $\left(E_{t}\right)$ indicates time rate of change of

501 kinetic energy, the second $\left(E_{k}\right)$ is divergence of kinetic energy flux, the third $\left(E_{p}\right)$ is

502 divergence of potential energy flux, and fourth $\left(E_{f}\right)$ is energy loss which is caused

503 by bottom, wall and internal frictions in water column. $E_{t}$ and $E_{k}$ are obtained

504 from integration of the observed cross-sectional velocity, $E_{p}$ is obtained from those

505 of sea level at the stations at the entrance of the strait and $E_{f}$ is derived from

506 these three terms as their residuals.

507 Fig. 2 shows the temporal variations of each term. $E_{t}$ and $E_{k}$ are relatively 508 small or negligible. The energy loss, $E_{f}$, reaches $2.5 \times 10^{4} \mathrm{Wm}^{-1}$ during maximum 509 ebb and flood. It is notable that the magnitude of $E_{f}$ changes according to the 510 current direction; it became larger in westward than that in eastward flow.

511 Significant horizontal shear has been observed in tidal currents, developed due to

512 the effect of the local geometry when the tidal current is toward the west. This

513 result indicates that internal friction in the water column significantly influences

514 the energy loss around the strait, as does bottom friction. 


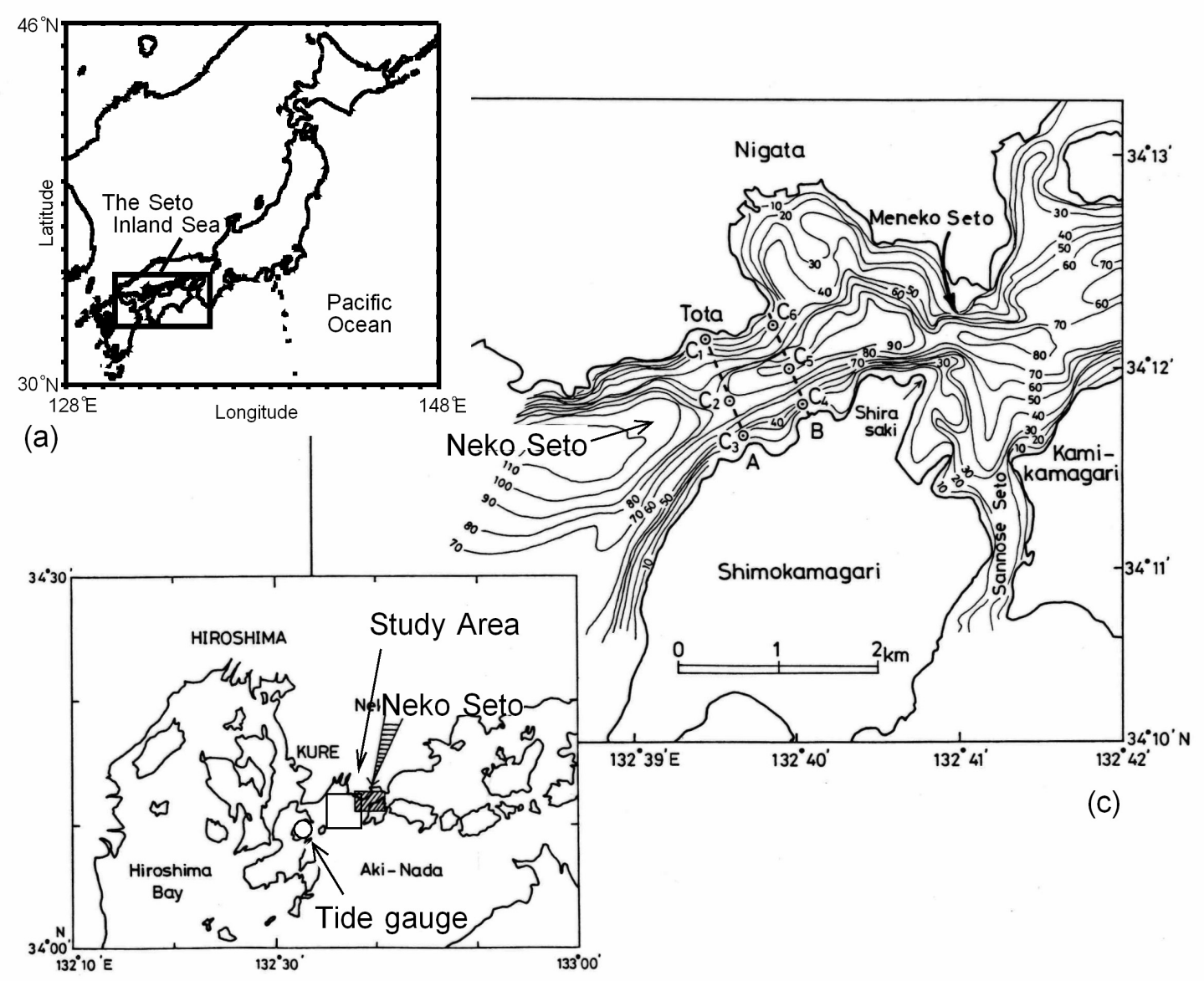

(b)

Fig. 1 (Kobayashi et al) 


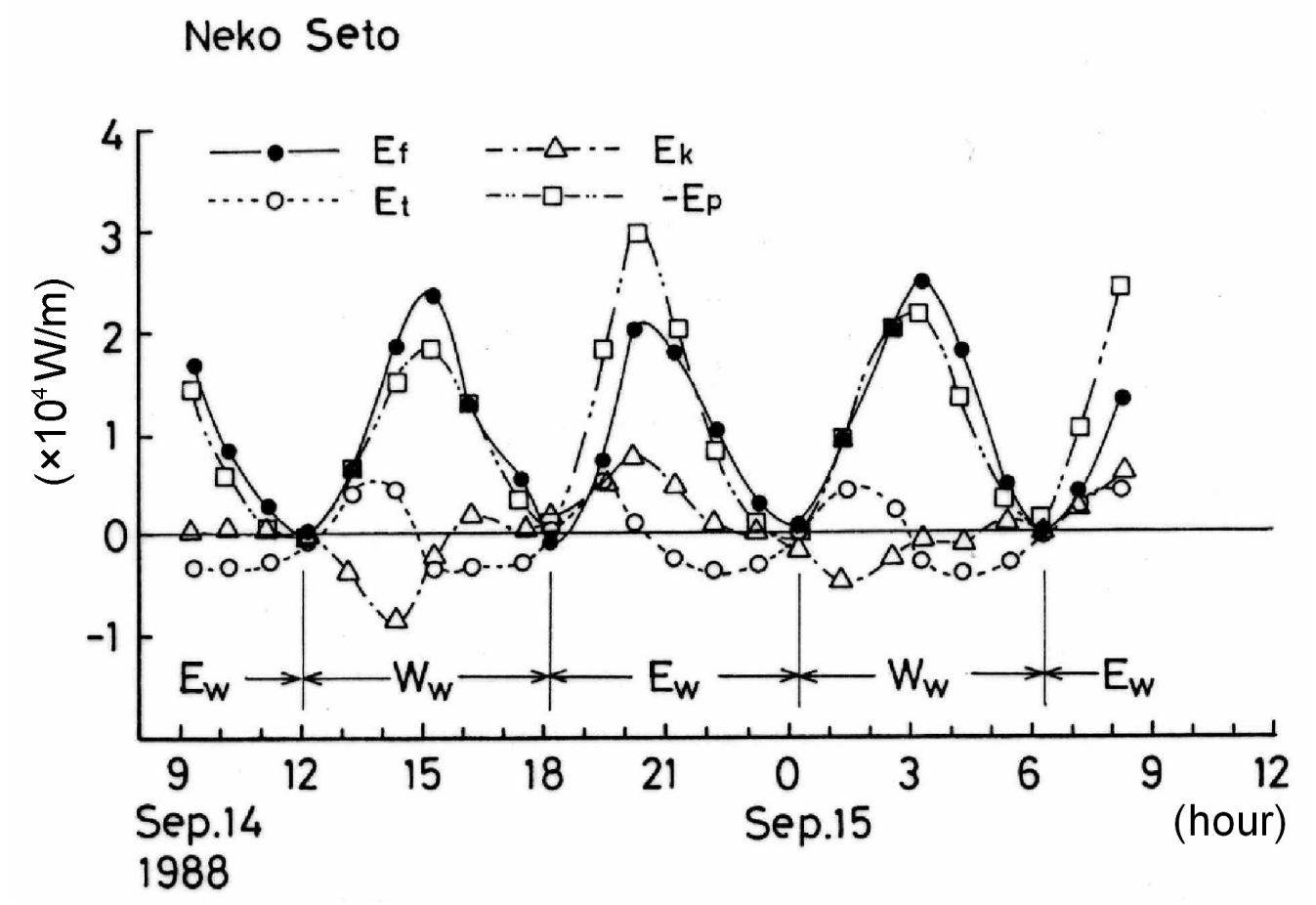

Fig. 2 (Kobayashi et al) 


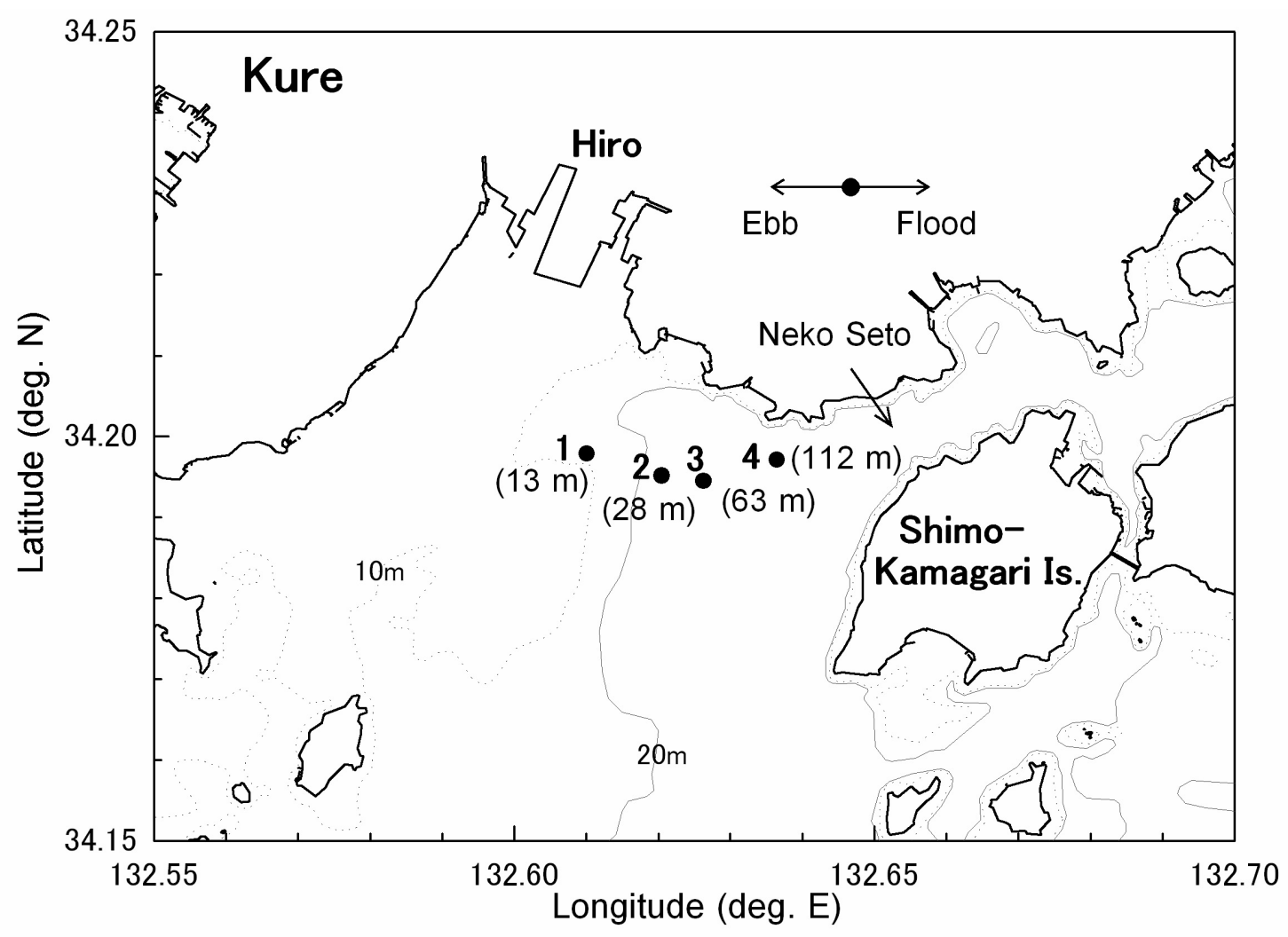

Fig. 3 (Kobayashi et al). 


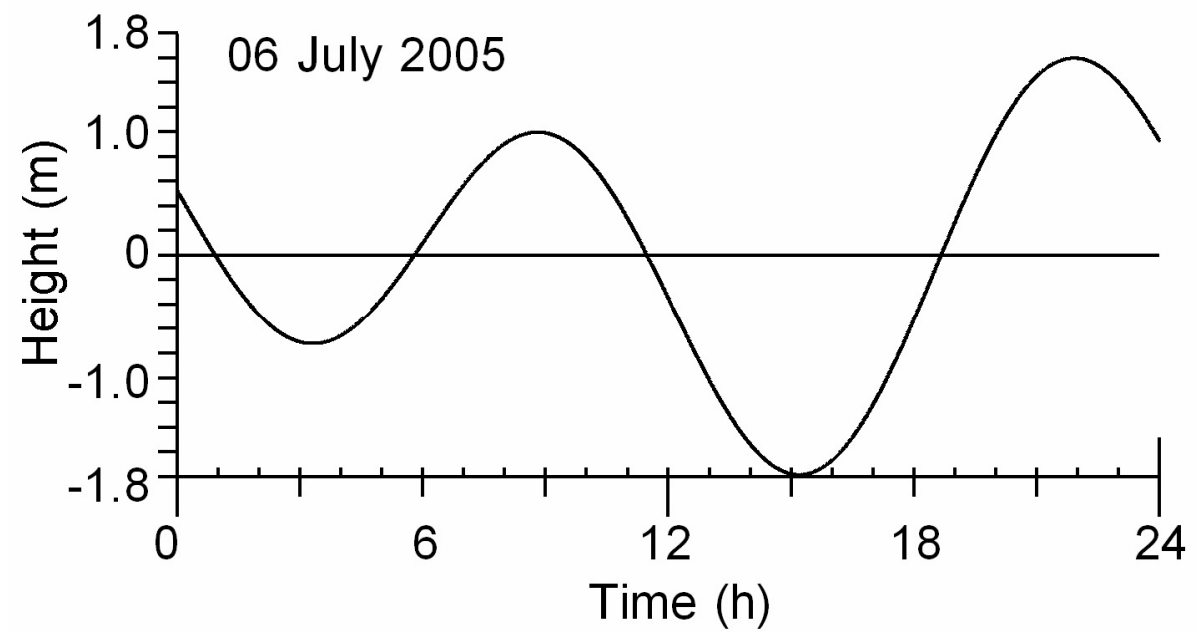

Fig. 4 (Kobayashi et al). 


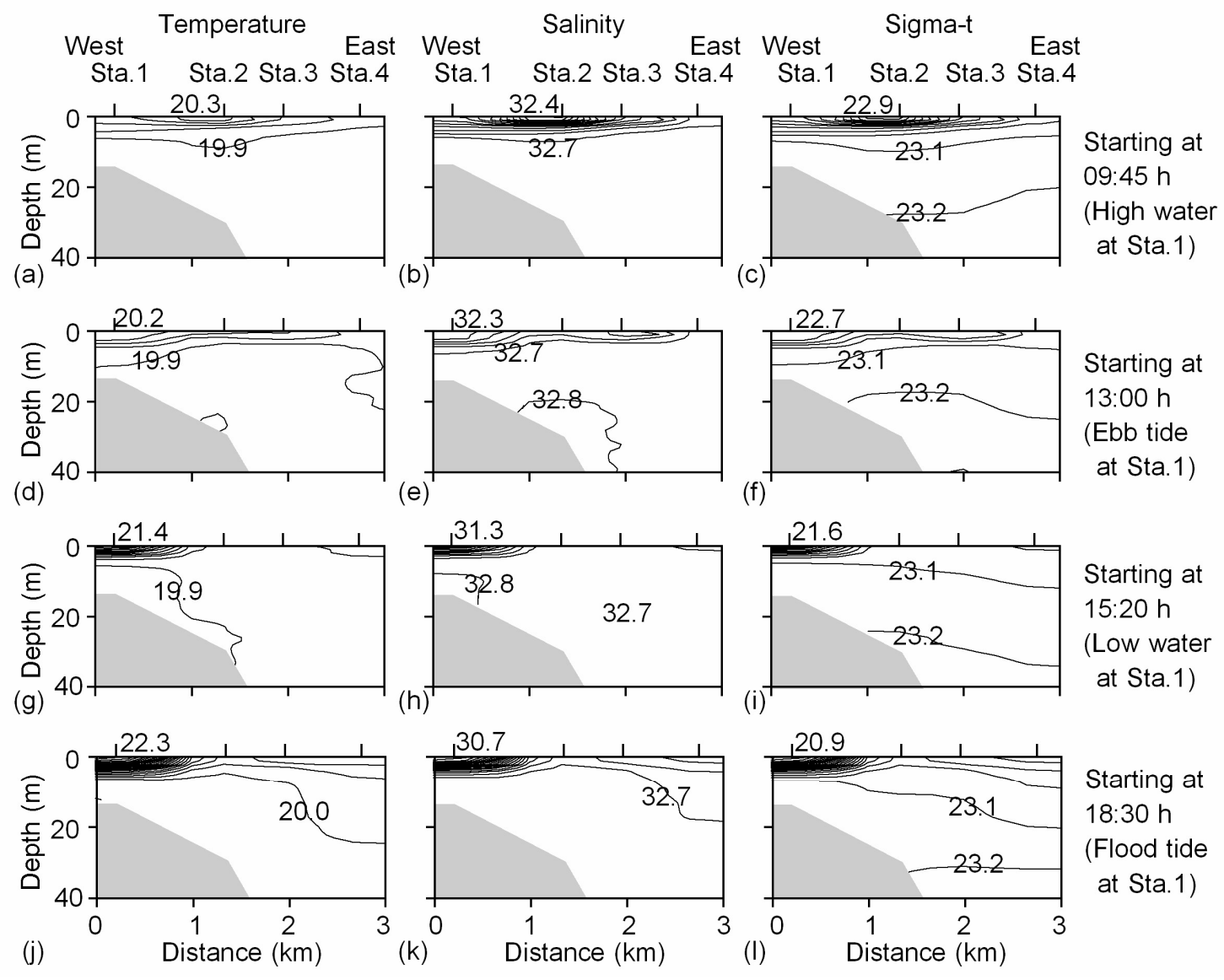

Fig. 5 (Kobayashi et al) 
(a)

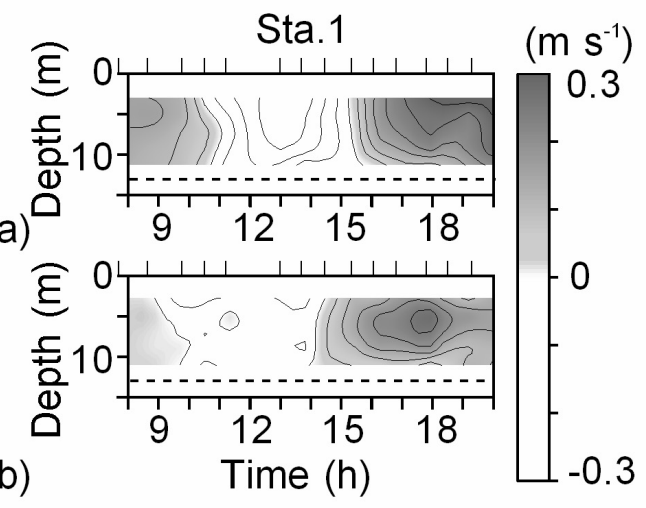

(b)

(e)

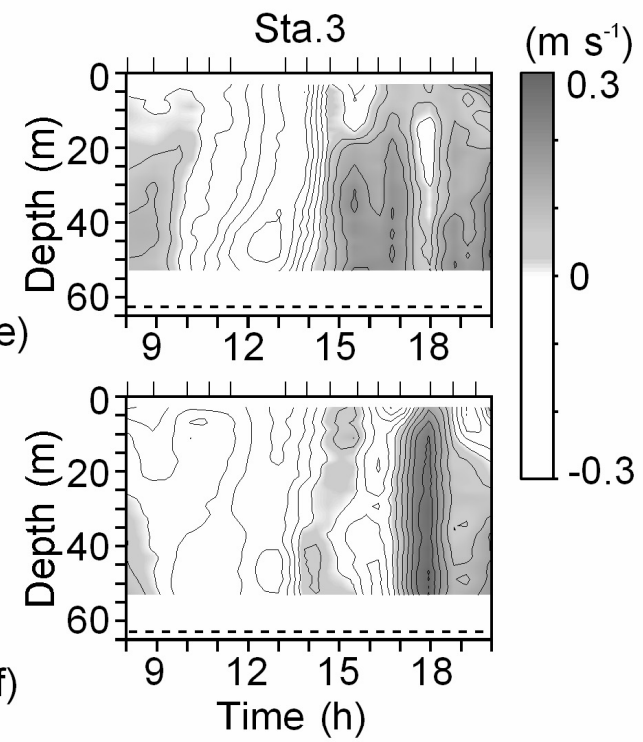

(d)

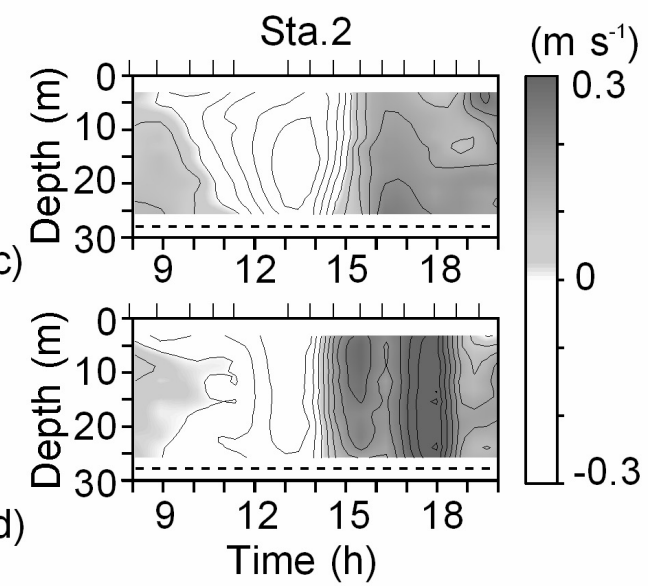

(g)

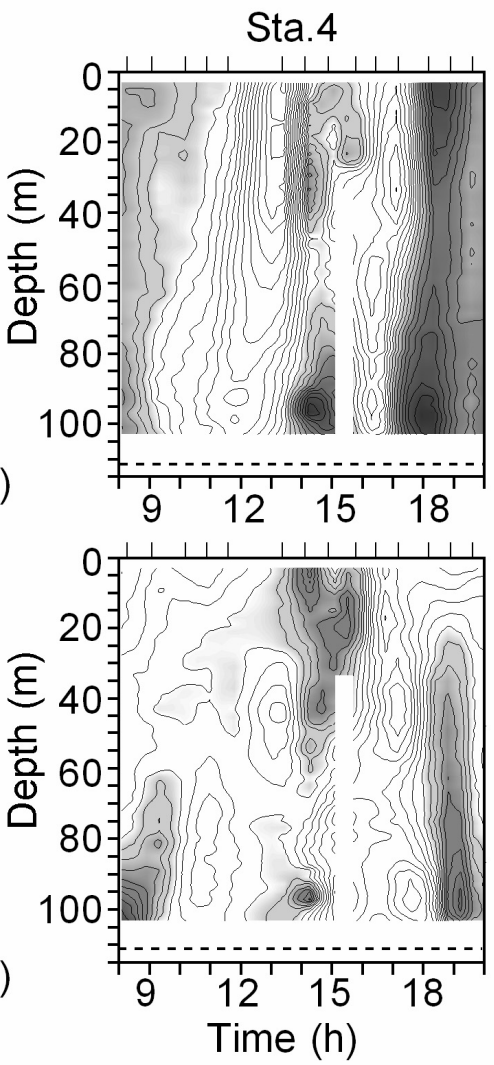

$\left(\mathrm{m} \mathrm{s}^{-1}\right)$

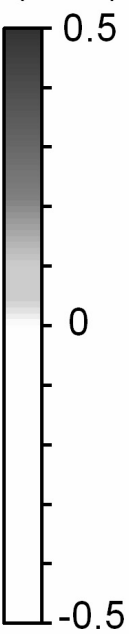

Fig. 6 (Kobayashi et al) 

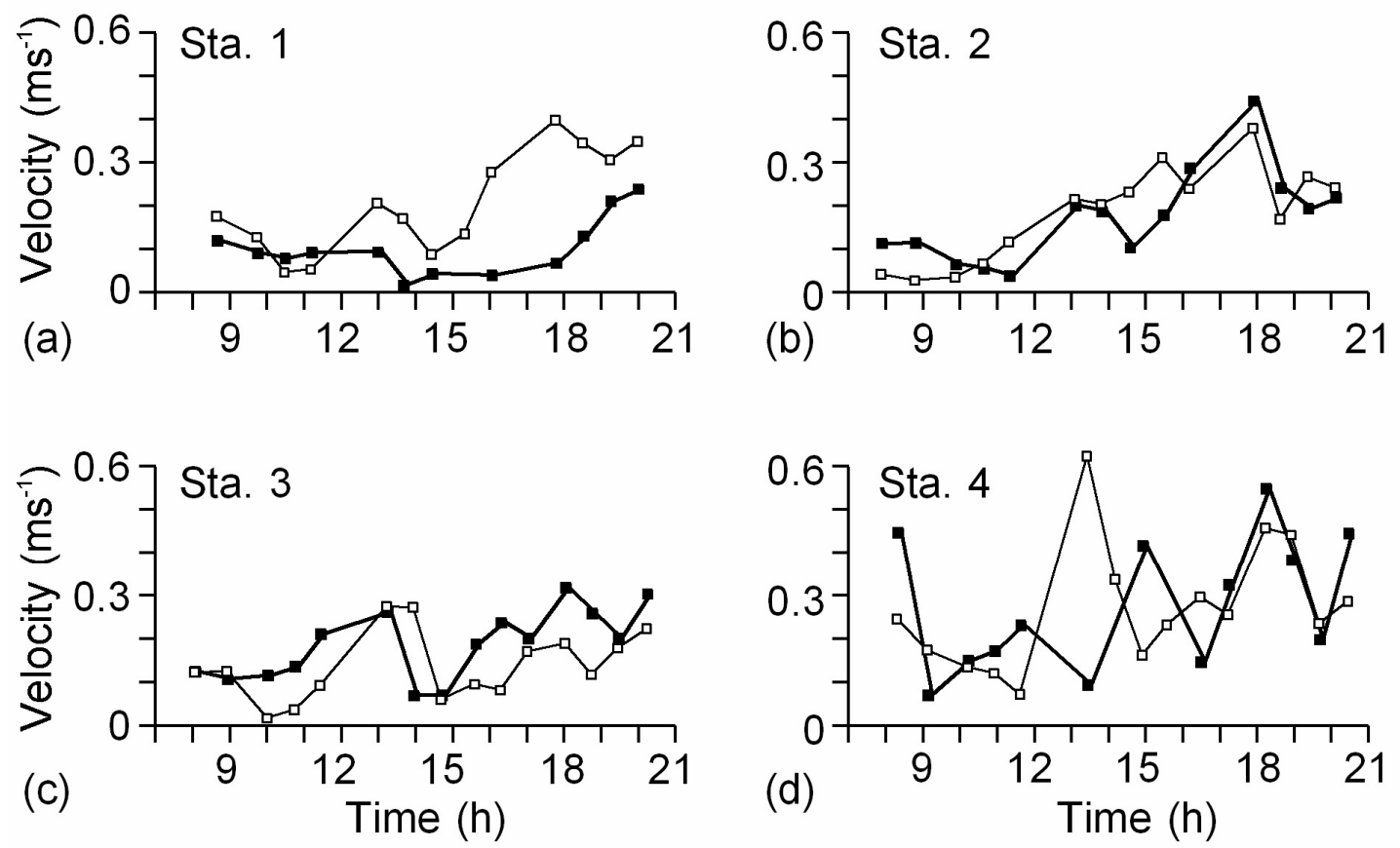

Fig. 7 (Kobayashi et al) 
(a)
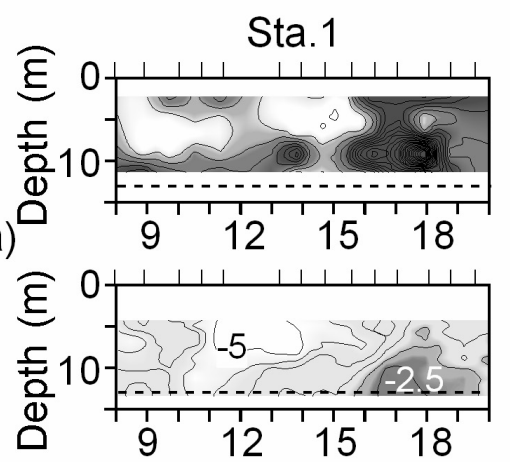

(b)

Time (h)

(e)

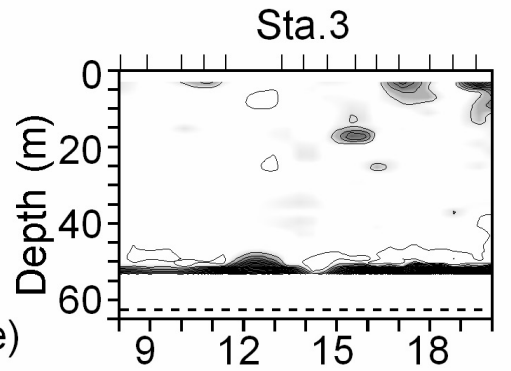

(f)

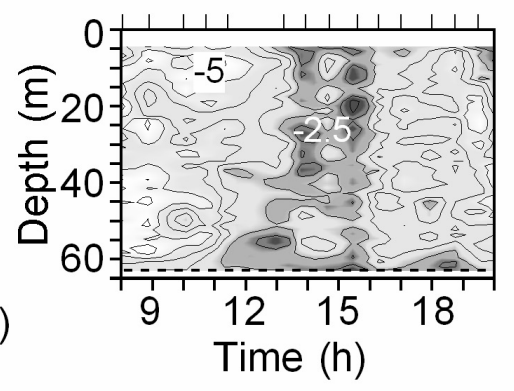

Sta. 2
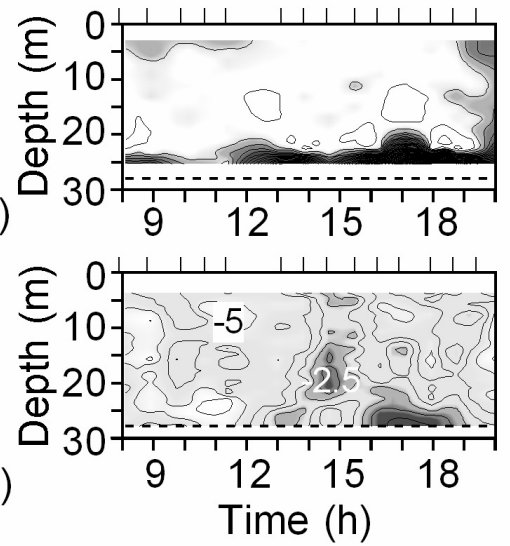

Sta. 4

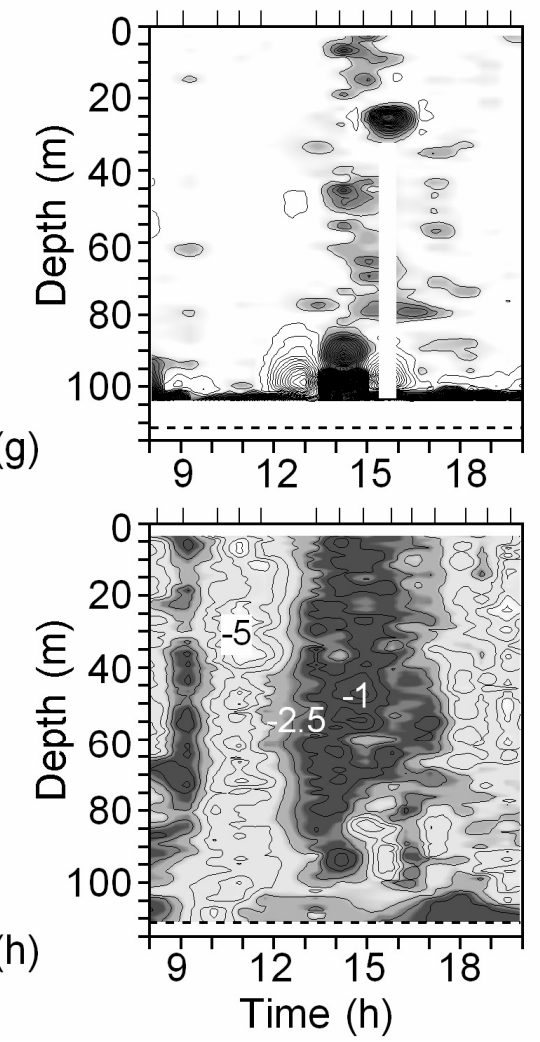

$\left(\frac{d u}{d z}\right)^{2}+\left(\frac{d v}{d z}\right)^{2}\left(\mathrm{~s}^{-2}\right)$

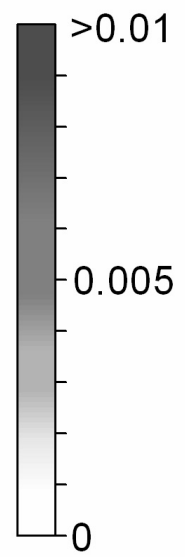

C.I. 0.002
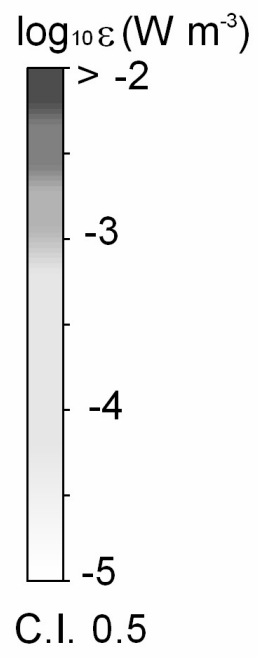

Fig. 8 (Kobayashi et al) 
10:10 (High water)

shear $\left(\mathrm{s}^{-1}\right)$

$\mathrm{u}\left(\mathrm{m} \mathrm{s}^{-1}\right)-0.2 \quad 0 \quad 0.2$ salinity

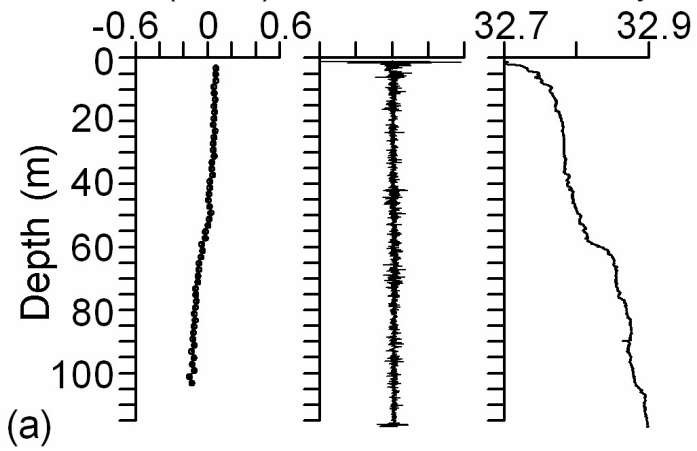

15:45 (Low water)

$$
\text { shear }\left(\mathrm{s}^{-1}\right)
$$

$\mathrm{u}\left(\mathrm{m} \mathrm{s}^{-1}\right) \quad-0.2 \quad 0 \quad 0.2$ salinity

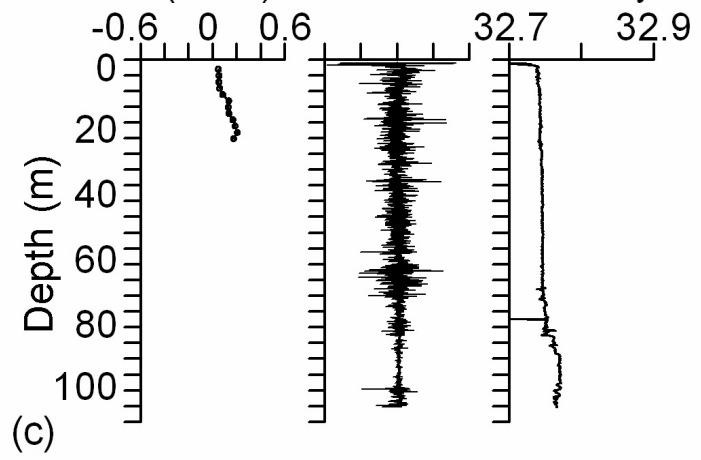

13:20 (Ebb tide)

shear $\left(\mathrm{s}^{-1}\right)$

$\mathrm{u}\left(\mathrm{m} \mathrm{s}^{-1}\right)-0.2 \quad 0 \quad 0.2$ salinity

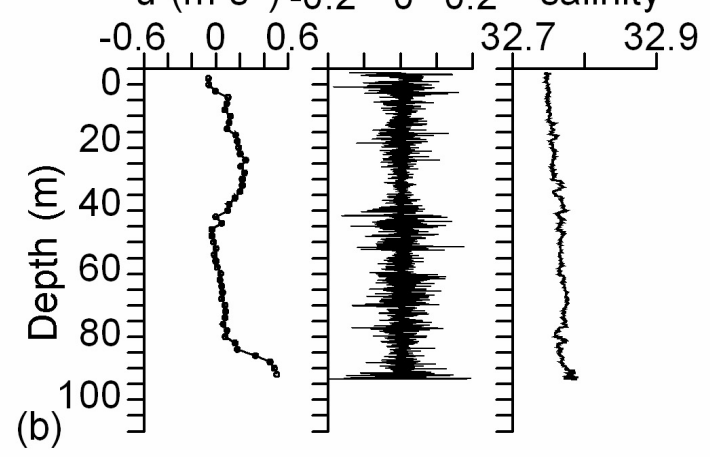

16:30 (Flood tide)

$$
\text { shear }\left(\mathrm{s}^{-1}\right)
$$

$$
\mathrm{u}\left(\mathrm{m} \mathrm{s}^{-1}\right)-0.2 \quad 0 \quad 0.2 \text { salinity }
$$

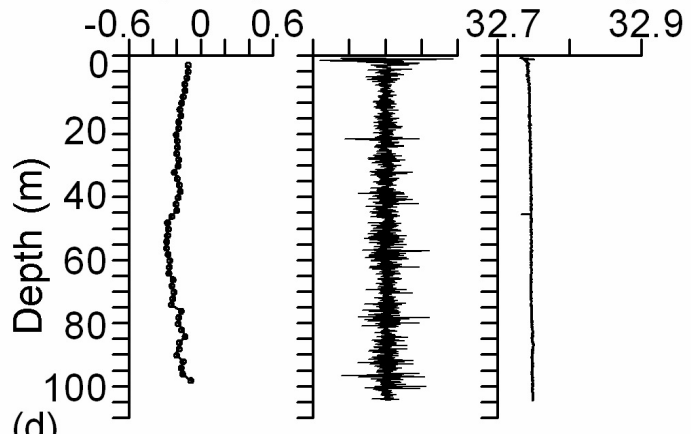

Fig. 9 (Kobayashi et al) 